\title{
Sarekat Islam: Gerakan Islam Modernis atau Tradisional?
}

\author{
Arif Rahim \\ Dosen Prodi Sejarah Fakultas Keguruan dan Ilmu Pendidikan Universitas Batanghari
}

\begin{abstract}
This paper discusses the position of Sarekat Islam (SI) as the largest and one of the most important organizations during the National Movement of 1900-1942, in the context of two large currents of Indonesian Islamic thought, namely traditional Islam and modernist Islam. Many historical works that do not explicitly explain the position of SI to the two groups have caused dissent. Through searching historical data about the 1912 Statutes and the speeches of SI leaders in the Bandung congress in 1916 it can be concluded that SI is an Islamic movement organization with a modernist style of Islam. However, this organization is less involved in the disputes between the reformers (Young People) and the traditions (Old People) compared to organizations that limit themselves in the social and educational fields.
\end{abstract}

Keyword: Islamic movements, modernist, traditional

\section{PENDAHULUAN}

Tulisan ini berangkat dari sebuah tanggapan yang disampaikan seorang peserta diskusi yang ditujukan kepada salah seorang panelis pada suatu diskusi publik bertemakan "Gerakan Sarekat Abang di Jambi (1900-1916)". Salah satu peserta mengatakan bahwa Sarekat Islam (SI) hanyalah semata-mata organisasi Islam tanpa embel-embel modernis sebagaimana yang melekat pada gerakan Muhammadiyah, atau Islam tradisional seperti yang melekat pada Nahdatul Ulama (NU). Pernyataan itu menjadi menarik untuk dijadikan sebuah tema tulisan karena mengandung arti belum jelasnya informasi dan pemahaman tentang eksistensi SI. Anggapan seperti di atas kemungkinan teranut dalam pikiran banyak orang termasuk kalangan akademisi yang berkecimpung dalam bidang kesejarahan. Persoalan ini menjadi penting karena SI adalah organisasi pergerakan nasional yang terbesar dan salah satu yang terpenting dalam sejarah bangsa Indonesia. Uraian sejarah tentang SI adalah pokok bahasan utama apa bila seseorang ingin memahami sejarah Indonesia pada periode pergerakan nasional 1900-1942. Kurang paham tentang SI dapat dikatakan kurang paham tentang sejarah Indonesia pada masa itu.

Penilaian peserta diskusi di atas bisa jadi berasal dari kesan gerakan Sarekat Islam yang lebih menonjol dalam bidang ekonomi dan perdagangan, kemudian politik, ketimbang bidang lainnya termasuk keagamaan. Programprogram organisasi di kedua bidang tersebut mengesankan bahwa SI adalah organisasi lintas mazhab keagamaan, bahkan cenderung lebih mengedepankan soal-soal kebangsaan. Dalam kalangan SI terdengar banyak ucapan yang memperkuat kesan-kesan tersebut. Pada suatu pidatonya tahun 1915 Tjokroaminoto mengatakan bahwa di kalangan bangsa Indonesia masih terlalu sedikit perasaan persatuan kebangsaan. Orang Madura tidak merasa satu dengan orang Jawa. Orang Jawa pun demikian dengan orang Sunda, dan orang Sunda demikian pula dengan orang Palembang. Namun demikian demi kemajuan dan kebangkitannya, di atas segala-galanya rakyat Indonesia harus bersatu hati. Sarana untuk mencapainya adalah agama Islam. Islam menghimpun semua orang karena tidak seorang pun di Indonesia yang mau disebut bukan orang Islam, walaupun sedikit sekali pengetahuannya tentang agama ini ( Korver, 1985 : 66). SI bahkan dapat dikesankan sebagai partai sekuler apa bila berkaca pada semboyan-semboyan dan tindakan tokoh SI yang berhaluan komunis seperti Semaun, Alimin, dan Darsono, dan lain-lain sebelum mereka dikeluarkan dari SI melalui kebijakan displin partai. Ketika itu mereka seringkali mengkritik sistem kapitalis yang diberlakukan oleh pemerintah kolonial dan melawannya dengan melakukan pemogokan.

Atas dasar itulah sebagian besar pengamat Eropa menilai bahwa agama dalam Sarekat Islam tidak merupakan faktor yang penting. Snouck Hurgronje menganggap SI bukan perkumpulan keagamaan. Menurut dia, dalam perkumpulan ini Islam hanyalah merupakan fungsi alat pengikat sosial politik yang membedakan bangsa Indonesia dengan bukan bangsa Indonesia. Rinkes juga berpendapat bahwa gerakan tersebut tidak memiliki sifat keagamaan yang khas. Demikian pula Idenburg juga mengemukakan pendapat dalam arti yang kira demikian. Frijling dan Clignett melihat pola yang sama dalam gerakan ini di Sumatera Selatan ( Korver, 1985: 65 ). Keterlibatan SI dalam berbagai pristiwa sejarah yang dinominasi kaum Islam tradisional bahkan kelompok abangan semakin mengaburkan pandangan orang tentang SI bila dikaitkan dengan keberadaan aliran keislaman yang ada di Indonesia. Pada peristiwa Sarekat Abang yang terjadi di Jambi 1916, Sarekat Islam bekerjasama dengan kalangan Islam tradisional. bahkan dengan golongan masyarakat abangan dalam suatu pemberontakan menentang kebijakan pajak yang diberlakukan penguasa kolonial (Aisjah Muthalib, 1995 : 155-157). 
Selain itu penilaian tampaknya didasarkan aspek kepemimpinan SI. Organisasi ini memang memiliki kepemimpinan dan keanggotaan yang beragam. Hingga diberlakukannya disiplin partai tahun 1923, keanggotaan SI dapat dikategorikan atas tiga kelompok. Pertama, kepemimpinan yang berpendidikan Barat meliputi orang-orang seperti Haji Agus Salim yang dipengaruhi oleh aliran-aliran reformis Islam, yang mendapat dukungan utama dari kelas menengah seperti pegawai negeri, serta unsur pedagang baik pribumi maupun Arab. Mereka menghendaki perubahan kehidupan agama dan sosial. Kedua, Kaum Marxis muda yang mendapat pengaruh kuat dari komunis Rusia, yang mencoba mengarahkan pergerakan tersebut menjadi suatu aksi yang radikal dan revolusioner, yang mengarahkan perhatiannya pada para pekerja di kota dan di perkebunan, serta orang-orang di pedesaan. Ketiga, kepemimpinan tradisional yakni SI Lokal yang bercirikan situasi setempat (Benda, 1985 : 64, MUI, 1991 : 230).

Namun keragaman itu bukan berarti mengaburkan identitas SI dalam kontek aliran pemikiran Islam. Keberadaan golongan sosialis komunis dalam tubuh SI lebih didasarkan kepada keinginan dalam hal memperjuangkan hak-hak kaum buruh dan petani yang umumnya beragama Islam dari penindasan toean-toean keboen, golongan Cina, dan ketidakadilan kebijakan pemerintah kolonial. Para pemimpin sosialis komunis itupun sebenarnya menyadari bahwa masuk SI adalah bagian dari strategi pencapaian tujuan sekaligus membangun kekuatan hingga mampu tampil sebagai organisasi dengan identitas sendiri. Terbukti setelah identitas kaum sosialis komunis ini makin jelas, maka organisasi memberlakukan disiplin atas mereka, dan mereka dikeluarkan dari partai. Sedangkan keberadaan golongan tradisi dalam SI lebih didasarkan pada semangat persatuan Islam dan perjuangan kebangsaan yang dianut para petinggi SI khususnya Tjokroaminoto, sekaligus jalan untuk mengembangkan gagasan modernisasi. Kelompok ini hampir tidak pernah mendapatkan posisi yang menentukan dalam struktur organisasi. Dengan demikian dapatkah SI dikatakan sebagai organisasi Islam Modernis?

Untuk menentukan posisi SI dalam konteks arus besar umat Islam Indonesia digunakan konsep Islam Tradisional dan Islam Modernis (pembaharu). Golongan Tradisi adalah golongan yang lebih banyak menghiraukan soal-soal agama, din atau ibadah belaka. Bagi mereka Islam seakan sama dengan fiqh dan dalam hubungan ini mereka mengakui taqlid, dan menolak ijtihad. Banyak pula memberi perhatian pada tasawuf. Walaupun gplongan ini mengaku menjadi pengikut mazhab, umumnya Syafi'i, mereka umumnya tidak langsung mengikuti ajaran mazhab itu, melainkan ajaran imam yang datang kemudian, sering pula ulama yang menyimpang dari ajaran pendiri mazhab itu. Golongan tersebut lebih banyak mengikuti fatwa yang telah ada, dan bukan cara pengambil fatwa itu. Dalam rangka tasawuf, banyak dari golongan ini jatuh pada perbuatan yang termasuk syirik, memperserikatkan Tuhan dengan bendabenda. Mereka menghormarti keramat, memberikan saji-sajian, mengadakan selametan atau kenduri sebagai sedekah terhadap arwah, dan memakai azimat, jimat, atau tangkal penolak bala untuk melindungi diri, semuanya dengan akibat mengaburkan pengertian tauhid. Sebaliknya, golongan pembaharu (modernis) lebih memilih perhatian pada sifat Islam pada umumnya. Bagi mereka Islam sesuai dengan tuntutan zaman dan keadaan. Islam juga berarti kemajuan, agama itu tidak akan menghambat usaha untuk mencari ilmu pengetahuan, perkembangan sains, kedudukan wanita. Islam adalah agama universal, yang dasar-dasar ajarannya telah diungkapkan oleh para nabi, baik yang dikenal maupun yang tidak, yang diutus kepada semua bangsa. Tugas mereka diselesaikan oleh Muhammad, rasul utusan terakhir untuk semua umat manusia. Menurut golongan ini, cita pikiran demikian dibentuk dalam syariat, hukum, atau jalan yang dapat dibagi dalam dua bagian. Bagian yang kedua dipecah pula menjadi dua. Pertama, iyalah apa yang disebut agama sebenar agama atau agama dalam arti sempit (din) yang terdiri dari ibadah (dalam arti sempit). Pada ajaran ini 'illa-nya, yaitu maksud, tujuan, dan sebab yang dikandungnya sering tidak jelas, tidak ma'kul, tetapi caracaranya diuraikan. Dalam din atau ibadah, semua terlarang, kecuali yang sudah disuruh, jadi cara-cara ibadah telah diperintahkan, dan di dalamnya barang baru tidak dapat diterima -ini disebut bid'ah. Pembagian kedua ialah, hal-hal yang bersangkutan dengan masalah dunia, masalah ini ada yang mengandung ciri agama, ubudiyah, juga dalam arti bahwa ia berdasarkan perintah Allah, tapi berbeda dari din atau ibadah, perintah ini ma'kul, jelas, dan diterangkan maksudnya, hanya saja pelaksanaannya tidak ditetapkan oleh agama, melainkan diserahkan kepada kita, asal bisa mencapai yang dimaksud oleh perintah itu sesuai dengan dunia atau zaman kita masing-masing. Zat perintahnya bersifat din, sedangkan cara mengamalkannya bersifat dunia. Umpamanya, perintah memelihara anak yatim, menghormati orang tua, membersihkan gigi, hal-hal yang sebagian besar pelaksanaannya terletak pada pilihan individu. Bagian lain ialah, yang bersangkutan dengan urusan keduniaan seratus persen, yang mungkin ada dan mungkin timbul berdasarkan adanya aaturan atau tidak dengan aturan agama. Dalam hal ini semuanya boleh, kecuali yang terlarang oleh agama. Yang perlu dijaga dalam hubungan ini adalah had, batas yang ditentukan agama, batas ini tidak boleh dilangar. Suatu hal yang sederhana adalah kebolehan makan dan minum apa saja, kecuali had yang ditentukan Al-Qur'an, yaitu; daging babi, khamar, darah, dan yang berlebih-lebihan. (Deliar Noer, 1985 : 320-323).

\section{METODE}

Masalah ini dibahas dengan menggunakan pendekatan historis yaitu suatu usaha untuk menyelidiki fakta masa lalu, melalui pembuktian, penafsiran dan penjelasan melalui fikiran kritis dari prosdur penelitian ilmiah. Dalam 
konteks ilmu sejarah prosedur penelitian ilmiah terdiri dari empat langkah yaitu heuristik, kritik, interpretasi dan historiografi.

\section{HASIL DAN PEMBAHASAN}

Jika diihat sisi dalam dari keberadaan tubuh SI itu sendiri, dapat ditangkap oleh pikiran bahwa sejatinya SI adalah gerakan Islam bercorak modernis. Indikasi yang paling sederhana terlihat dari buku Deliar Noer yang berjudul Gerakan Moderen Islam di Indonesia 1900-1942 yang diterbitkan LP3ES pertama kali 1980 dan dicetak berulangkali. Dalam buku itu SI adalah bahasan utama. Dengan menjadikan SI sebagai bahasan utama pada sebuah buku yang berjudul Gerakan Moderen Islam, seolah pengarangnya menggolongkan SI sebagai gerakan kalangan pembaharu.

Tentu saja alasan itu tidak cukup untuk menyimpulkan corak dari sebuah organisasi gerakan Islam. Bisa saja sebuah organisasi Islam yang bermazhab tradisional, namun karena dikelola sebagaimana layaknya organisasi moderen, maka dapat saja dimasukkan ke dalam kategori gerakan moderen Islam, namun organisasi itu tidak dapat disebut organisasi Islam modernis. Sebagai contoh Nahdatul Ulama (NU), sejak lahirnya adalah sebuah organisasi Islam yang dikelola secara modern namun tak bisa dikatakan sebagai gerakan Islam modernis.

Kembali kembali ke soal buku Deliar Noer di atas, di dalamnya terdapat sub judul " Pertikaian Dalam Kalangan Pembaharu". Bagian ini membahas pertikaian antara Syarekat Islam dengan Muhammadiyah maupun dengan Persatuan Islam ( Persis ). Uraian itu dengan demikian menegaskan bahwa SI tergolong organisasi Islam bercorak modernis (Noer,1985 : 255-260)

Indikasi "kemordernisan" yang lebih jelas, terlihat dari Anggaran Dasar dan Anggaran Rumahtangga (AD/ART) SI tanggal 10 Sepetember 1912, pasal 2 ayat d. :

Menghilangkan salah pengertian mengenai agama Islam dan memajukan kehidupam keagamaan dikalangan bumi putera sesuai dengan hukum tatacara dan agama tersebut : menempuh segala cara dang menggunakan semua jalan yang diperkenankan dan tidak bertentangan dengan ketentraman umum dan adat istiadat yang baik ( Corver,1982 :208)

Kalimat "menghilangkan salah pengertian mengenai Islam" adalah kalimat yang lazim diungkakan oleh kalangan ulama modernis atau pembaharu, dalam mengkritisi realitas keagamaan yang dinilai menyimpang dari ajaran Islam yang sebenarnya. Penyimpangan itu berakar pada kepercayaan-kepercayaan maupun agama lama masyarakat Indonesia sebelum kedatangan agama Islam. Penyimpangan-penyimpangan itu secara sederhana dapat digolongkan pada praktek perbuatan tahyul, bid ah, dan khurafat (Syaifullah, 1997 : 37-43).

Sebelum Islam datang penduduk Nusantara mempunyai kepercayaan bahwa bukan hanya manusia yang mempunyai jiwa, hewan, dan tumbuh-tumbuhanpun juga berjiwa. Mereka mempercayai dan menyembah arwah orang yang sudah meninggal karena ada anggapan bahwa orang yang sudah meninggala mempunyai pengaruh yang kuat dan langsung terhadap orang-orang yang masih hidup. Selain itu mereka mempercayai kekuatan segenap benda yang ada di sekelilingnya mulai dari sungai yang mengalir, air bah, matahari, dan tempat-tempat yang menyeramkan, seperti pohon beringin, dan gunung-gunung yang tinggi. Kepercayaan inilah yang disebut dinamisme. Orang-orang tua yang mengerti hal-hal tersebut, dapat menjawab segala yang dipertanyakan. Dan etelah orang-orang itu meninggal, mereka mempertanyakan apa arti hidup dan mati yang dipercaya ada di luar badan kasar, dan juga mempertanyakan apa yang harus diperbuat pada badan kasar yang sudah mati. Seringkali badan kasar yang telah mati tidak dikuburkan, tetapi disimpan di tempat khusus di tengah keluarga, atau dibawa ke puncak bukit, sebab pengaruhnya masih terasa di kalangan keluarganya. Kadang-kadang orang yang telah meninggal itu terbayang dan dijumpai dalam mimpi, memberi nasihat, minta dipuja, dan lain-lain. Dengan kata lain, mereka peraya pada arwah nenek moyangnya. Kepercayaan ini lah yang disebut Animisme. Selain itu, kadang-kadang setelah orang tua (Bapak, Nenek, Kakek, atau kepala keluarga) meninggal, beberapa hari kemudian terdengarlah suara harimau di tengah malam, di dekat rumah orang yang telah meninggal itu, maka timbul lah kepercayaan bahwa orang tua itu telah menjadi jadi-jadian berupa riharimau, buaya, atau ikan. Dengan kata lain, mereka percaya akan hubungan antara manusia dengan nenek moyang binatang. Kepercayaan ini dinamakan Totemisme. Dinamisme, Animisme, dan Totemisme dalam banyak hal senafas dengan ajaran Hindu dan Buddha, yang belakangan masuk ke Nusantara.

Sejak abad ke-5, di Nusantara, telah terdapat negara-negara yang bercorak Hindu-Buddha. Di Sumatera, terdapat Kerajaan Melayu dan Sriwijaya, di Jawa, terdapat Kerajaan Majapahit dengan patihnya yang terkenal Gadjah Mada, di Sunda terdapat Kerajaan Padjajaran, dan di Kalimantan terdapat Kerajaan Kutai. Sedangkan di Bali, Kerajaaan bercorak Hindu masih tampak sampai dengan abad ke-20.

Pada umumnya, perekonomian kerajaan-kerajaan tersebut tergantung pada perdagangan laut dan pertanian. Untuk Kerajaan di kawasan Sumatera dan Kalimantan, perekonomiannya bergantung kepada perdagangan laut, seperti juga Kerajaan di Selat Malaka, Sumatera Utara, serta Kalimantan Timur dan Utara. Sedangkan, Kerajaan di Jawa, seperti Kediri, Singhasari, dan Majapahit, perekonomiannya tergantung pada pertanian. 
Di antara kerajaan-kerajaan pesisir di Sumatera dan Kalimantan, dan kerajaan-kerajaan pedalaman di Jawa, selalu terdapat pertentangan karena perebutan kekuasaan. Dalam pertentangan politik itu, unsur agama belum ikut memegang peranan. Namun setelah proses islamisasi berlangsung, unsur agama memegang peranan penting.

Tidak diketahui secara pasti kapan agama Hindu dan Buddha masuk ke Indonesia. Namun, setelah adanya penelitian tentang kerajaan Kutai 400 M di Kalimantan Timur, dan Tarumanegara di Jawa Barat pada abad ke-5, yang mana keduanya bercorak Hindu, maka Hamka menyimpulkan bahwa pengaruh Hindu boleh telah ada di Nusantara sejak abad kedua, karena patung-patung Buddha yang ditemukan di Samogapa (Sulawesi), Jember (Jawa Timur), dan dekat Palembang (Sumatera Selatan), diperkirakan dibuat sebelum abad kelima.

Keberadaan agama Hindu dan Buddha dalam perkembangannya di Indonesia berjalan bersama-sama, sehingga secara teoretis orang sangat sukar membedakan Shiwa dan Buddha yang disembah dalam agama Hindu dan Buddha. Namun pengaruh Hindu/Buddha di pulau Jawa dan Sumatera berbeda. Di Sumatera ( umumnya di luar Jawa) pengaruh Hindu/Budha tidak terlalu kuat karena umumnya kerajaan-kerajaan luar jawa bercorak maritim. Dalam hal ini kedatangan agama Islam langsung berhadapan dengan unsur kepercayaan asli yang dalam banyak hal sudah sejalan dengan ajaran Islam. Sebaliknya hindunisasi di pulau Jawa tumbuh secara mendalam dan masih meninggalkan bekasnya sampai sekarang. Hindu, dengan kekuatan politiknya, menancapkan akar-akar kebudayaannya ke dalam masyarakat Jawa. Agama Hindu menjadi agama kerajaan, dan Mataram (Yogyakarta-Surakarta) merupakan kerajaan yang paling dalam terkena pengaruh Hindu.

Ketika agama Islam datang ke tanah Jawa Islam (l.k abad 14), Islam menghadapi pengaruh kebudayaan Hindu yang kuat yang berjalin berkelindan dengan unsur kebudayaan asli. Dalam konteks ini proses masuk dan berkembangan Islam mengalami " dialog” pergumulan budaya yang panjang sehingga menampakan corak Islam yag tidak "murni”" (Syaifullah, $1997: 40$ ).

Proses pengembangan Islam di Jawa dilakukan secara adaptasi dengan pendekatan kebudayaan yaitu dengan menggunakan lambang-lambang budaya lokal sebagai media penyampaian Islam kepada masyarakat setempat. Pola dakwahnya dilakukan memakai dua jalur. Jalur pertama menggunakan para wali yang memakai lambang-lambang dan lembaga budaya Jawa, daan jalur kedua melalui lembaga pendidikan yang bernama pondok pesantren.

Pola pertama dilakukan para wali langsung ke daerah-daerah pedesaaan dengan melakukan metode akulturasi dan sinkretisasi. Konskuensi cara ini Islam tidak hanya menjinakkan sasarannya, melainkan juga menjinakkan dirinya sendiri. Dari penjinakan demikian lahirlah Islam dengan corak tersendiri yang oleh Hamka disebut Islam yang memuja kubur wali dan sebagainya. Corak Islam yang demikian yang disebut Islam kejawen yang oleh Geertz disebutnya agama Jawa. ( Geertz, : 1989) Penganut Islam kejawen adalah penganut Islam tetapi tidak menjalankan kewajiban ritual. Contoh akulturasi adalah perayaan sekaten yang berasal dari kata syahadatain (dua kalimah syahadat) untuk memperingati peringatan maulud nabi Muhammad, serta wayang ketan-kolak-apem yang berasal dari bahasa arab khataan qala afuwun.

Dalam bidang kepercayaan dan ibadah terdapat khurafat dan bida ah. Khurafat adalah kepercayaan tanpa pedoman yang sah dari Al Qur an dan hadist sahih. Hanya ikut-ikutan orang tua dan nenek moyang. Bentuk khurafat adalah mohon kepada mbahurekso. Adapun bid ah adalah perbuatan memperbanyak ibadah (ritual) namun tak bersumber pada ajaran Islam. Contohnya acara selamatan ataupun tahlilan yang menggunakan lafal Islam. Selamatan adalah suatu upacara kultural untuk memenuhi suatu hajat yang berhubungan dengan suatu kejadian yang ingin diperingati. Maksud acara ini adalah agar kelak mereka yang mengadakan atau yang diselamati eroleh keselamatan. Masyarakat Jawa pada umumnya mengadakan upacara selamatan dalam berbagai peristiwa, seperti kelahiran, khitanan, perkawinan, kematian, pendah rumah, paperingatan bagi oranen,dan membuka usaha. Selamatan ini selalu diiringi dengan tahlil secagai cara mengirim doa. Proses tahlil dimulai dengan membaca al Fatihah kepada keluarga Nabi dan sahabatnya,kemudian surat alIkhlas tiga kali, surat al Falaq, surat an Nas, al Fatihah, permulaan surat al Baqarah, ayat Kursi, dan beberapa doa dalam Al Quran yang terdapat di akhir surat Al Imran.Selanjutnya membaca zikir, istigfar dan tasbih dalam jumlah tertentu dan diakhiri dengan doa yang dibacakan oleh pemimpin tahlil.

Bentuk lain dari khurafat adalah pengkeramatan kuburan orang suci. Biasanya orang berziarah ke kubur sambil meminta restu atau pertolongan dari roh orang yang telah meninggal dunia. Ziarah ke kubur memang dianjurkan alam ajaran Islam dengan maksud untuk mendoakan orang yang telah meninggal, dan sekaligus untuk peringatan bagi peziarah bahwa satu saat dia juga akan meninggal. Namun yang diluar ajaran Islam adalah doa minta restu, berkah dan pertolongan kepada roh orang yang sudah meninggal.

Upaya pemurnian terhadap ajaran Islam biasanya ditempuh dengan dua cara. Pertama dengan cara kekerasan seperti yang ditempuh gerakan paderi di Sumatera Barat. Kedua membentuk organisasi pendidikan, sosial, dan dakwah Sarekat Islam beserta banyak organisasi lainnya pada masa pergerakan pada paruh pertama abad 20 menempuh cara kedua meskipun gesekan-gesekan pisik dalam skala kecil kerap terjadi.

Gambaran cara berpikir reformis terungkap dalam pidato tokoh-tokoh lapisan atas SI seperti Joyopranoto, Ardiwinata, dan Abdoel Moeis yang disampaikan pada konggres di Bandung 1916. Menurut Joyopranoto, rakyat Indonesia dapat mencapai kemajuan melalui dua cara yaitu melalui pengetahuan Barat dan melalui Islam. Pertama 
memberikan alat-alat teknis untuk ini. Tarekhir mengajarkan kepada manusia agar jangan malas dan harus bekerja keras demi kesejahteraannya sendiri dan sesamanya baik di dunia maupun di akhirat. Gabungan kedua unsur Barat dan Islam diperlukan untuk mencapai tujuan kemajuan. Di beberapa negeri Islam seperti di Mesir dan Turki dan dikalangan golongan Muslim di India orang merasa bahagia berhasil memadukan keduanya. Di sini terdapat banyak ahli hukum yang modern dan ttidak keberatan terhadap mereka yang dididik secara Barat dan telah menyerahkan diri pada tuntutan-tuntutan masa sekarang.

Selanjutnya Joyopranoto mengemukakan bahwa di Indonesia masih terdapat jurang yang dalam anatara Islam di suatu pihak dan pikiran-pikiran Barat modern : satu pemisahan yang merupakan rintangan besar bagi kemajuan rakyat Indonesia. Di satu pihak terdapat mereka yang menghabiskan seluruh waktunya untuk agama seperti-guru-guru agama maupun para kiai. Namun umumnya mereka ini fanatik dan konservatif. Dipikah lain terdapat cendikiawan Indonesia berpendidikan Barat yang tidak begitu paham dalam soal agama, tapi haus akan pengetahuan Islam yang sejati. Itutak dapat dipenuhi oleh para kiai tersebut. Pada Syarekat Islamlah terdapat tugas untuk menutup jurang antarakedua kelompok ini. Untuk ini didirikan sekolah pendidikan guru Islam untuk guru agama atas dasar modern yang akan merupakan langkah pertama ke arah yang benar.

Senada dengan Joyopranoto, Ardiwinata juga mengatakan besarnya jarak yang memisahkan guru-guru pesantren kolot yang pemperoleh pendidikan Islam tradisional di satu pihak, dan para cendikiawan Indonesia yang mendapat pendidikan Barat modern di sekolah-sekolah pemeruntahan di lain pihak. Untuk itu menurut dia Syarekat Islam berusaha untuk menciptakan pendidikan Islam atas dasar modern.

Sementara Abdoel Moeis dalam pidatonya lebih menekankan pada masalah-masalah kegiatan penginjilan agama-agama Kristen (kristenisasi) di Indonesia yang lama kelamaan dapat merupakan bahaya bagi Islam. Selanjutnya ia mengemukakan keistimewaan-keistimewaan ajaran Islam yang antara lain memiliki peraturanperaturan yang baik danmenganjurkan manusia untuk berbuat baik, bekerja keras mencari nafkah sendiri serta mengembangkan kerohanian. Dengan demikian Islam mendorong kemajuan dan kesejahteran. Islam juga punya ajaran membangkitkan kecintaan terhadap bangsa dan negerinya sendiri. Oleh karena sifat-sifat yang baik itu maka merupakan tugas Syarekat Islam untu meningkatkan iman. Abdoel Moeis pun sampai pada kesimpulan bahwa yang akhir ini dapat dilaksanakan sebaik-baiknya dengan memperbaiki dan modernisasi pengajaran Islam ( Korver, 1982: 70-71).

Indikasi Sarekat Islam sebagai organisasi Islam modernis juga dapat diketahui dari penjelasan tokoh-tokoh Syarekat Islam di daerah Palembang, ketika mereka menolak tuduhan pemerintah kolonial yang menuduh mereka terlibat dalam pemberontakan Sarekat Abang yang terjadi di daerah Sumatera Selatan dan Jambi tahun 1916. Mereka menegaskan bahwa SI tidak pernah mengenal onderbouw yang bernama Sarekat Abang (SA). Menurut SI Palembang ajaran yang dikembangkan SA mengandung aliran mistik atau tarekat dengan menggunakan beberapa simbol tertentu, seperti pakaian merah dan sejumlah lafaz doa yang diwajibkan kepada setiap anggota. Semua itu bukan doktrin SI.

Sanggahan itu memang cukup beralasan karena hampir semua pengurus SI di Sumatera Selatan adalah pendukung Kaum Muda. SI yang hingga akhir 1920an sudah tersebar di Sumatera Selatan hingga daerah pedalaman, tampil sebagai gerakan keagamaan. Organisasi ini menjalin kerjasama dengan Muhammadiyah terutama dalam hal pendidikan sekolah dan bidang sosial lainnya. Dibantu oleh tokoh-tokoh ulama terkenal seperti KH. Kaharoeddin, H. Akil, H. Ridwan, Muhammad Rusli, R. Subono Poerwawiyoto Pengurus SI membentuk badan koperasi dan membeli sebuah motor- boot seharga f.4000 sebagai modal awal koperasi. Selanjutnya mereka mendirikan serikat dagang bernama Perkoempoelan Dagang Islam Palembang. Perkumpulan ini kemudian berganti naman menjadi Perkoempoelan Dagang Bangsa Melajoe. Untuk memajukan pendidikan didirikan Sekolah Aliyyah Diniyah yang sekaligus berfungsi sebagai markas gerakan. Di daerah Ranau mereka membuka madrasah bernama Al Irsyad. Selain itu mendirikan koperasi yang diberi nama Kemajdoean Kaoem Moeslimin. Dalam rangka menindak lanjuti himbauan Pengurus Pusat SI HOS Tjokroaminoto ketika berkunjung ke Palembang tahun 1919 yang mana ia menganjurkan "kepintaran yang lahir" serta "kepintaran yang batin" (Agama) bagi SI, maka pengurus SI Bratanata mendirikan surat kabar bernama Pertja Selatan yang berfungsi sebagai saluran aspirasi kaum pergerakan melalui berbagai tulisan yang diterbitkan di surat kabar itu. Sejak tahun 1926 SI yang telah berganti nama menjadi PSII bersama Muhammadiyah tampil sebagai juru bicara kaum modernis Islam dan kerap berhadapan dengan kaum tua yang banyak disokong pemerintah kolonial (Mestika Zed, 2003 : 139-147).

Penilaian SI sebagai organisasi Islam modernis juga bisa dilihat dalam hal pembicaraan masalah pembentukan khalifah Islamiyah. Setelah kekhalifahan dihapuskan oleh pemerintahan sekuler Turki di bawah pimpinan Kemal Attaturk.. Masalah kekhalifahan mendapat perhatian besar dari umat Islam, termasuk Umat Islam Indonesia baik dari kalangan modernis maupun tradisional. Kekuasaan Sultan Turki yang dipandang sebagai khalifah termasuk oleh umat Islam Indonesia, semula dibatasi pada tahun 1922, dan dihapuskan sama sekali tahun 1924. Pristiwa itu menimbulkan kebingungan kalangan dunia Islam . Pada waktu para pemimpin Islam mulai berpikir tentang pembentukan khilafat baru. Masyarakat Islam Indonesia bukan hanya berminat dalam masalah ini, seligus merasa berkewajiban memperbincangkan dan mencari penyelesaiannya. Kebetulan Mesir bermaksud menyelenggarakan kongres tentang 
khilafat. Sebagai sambutan atasmaksud tersebut umat Islam Indonesia membentuk Komite Khilafat di Surabaya pada tanggal 4 Oktober 1924. Terpilih sebagai ketua Wondoamiseno dari Sarekat Islam, dan KH. A.Wahab Hasbullah dari kalangan tradisi sebagai wakil ketua. Kongres Al Islam ketiga di Surabaya pada bulan Desember 1924 antara lain memutuskan mengirim delegasi kongres ke Kairo terdiri dari Surjopranoto (SI), H.Fachruddin (Muhammadiyah), dan KH. A. Wahab dari kalangan tradisi.

Kongres Kairo ditunda dengan berbagai alasan. Namun pembicaraan masalah khilafat tetap menjadi perhatian serius ketika Ibnu Sa'ud menjadi penguasa baru tanah suci menggantikan Syarif Husein yang tersingkir ke Yordania. Suatu undangan yang dikirimkan oleh raja Sa ud kepada umat Islam Indonesia untuk menghadiri kongres di Mekah dibacarakan dalam kongres Al Islam keempat 21-27 Agustus 1925 di Jogyakarta, dan kongres Al Islam kelima di Bandung 6 Februari 1926.

Yang menarik dalam kaitan tulisan ini adalah, sebelum kongres yang dilangsungkan di Bandung diadakan rapat antara organisasi-organisasi pembaharu yang berlangsung di Cianjur pada 8-10 Januari 1926. Dalam pertemuan itu diputuskan Cjokroaminoto dari SI dan KH. Mas Mansur dari Muhammadiyah sebagai utusan yang akan dikirim ke Mekah untuk mengikuti kongres. Pertemuan Cianjur ini semakin mempertegas bahwa SI berada di dalam barisan kalangan Islam Modernis.

Dalam kongres yang berlangsung di Bandung itu, KH. A. Abdul Wahab atas nama kalangan tradisi mengusulkan agar kebiasaan-kebisaan agama, seperti membangun kuburan, membaca doa seperti dalail al khairat,ajaran mazhab agar dihormati oleh kepala negara Arab yang baru di negaranya, termasuk di Makah dan Madinah. Kongres di Bandung itu tidak menyambut baik usul-usul itu sehingga Wahab dan tiga orang penyokongnya keluar dari Komite Khilafat, dan selanjutnya mengambil inisiatif utnuk mengadakan rapat-rapat kalangan ulama Kaum Tua. Rapat-rapat mulanya diikuti oleh ulama dari Surabaya kemudian juga dari Semarang, Pasuruan, Lasem dan Pati. Mereka bersepakat untuk mendirikan suatu panitia yang disebut " Komite Merembuk Hejaz. Komite nilah yang nantinya berubah nama menjadi Nahdatul Ulama tanggal 31 Januari 1926 ( Noer, 1985 : 241-243).

Modernisme SI tidak hanya terpantau dari segi aspek pemikiran, tetapi tampil dalam sikap permusuhan, intoleransi, ataupun boikot dan kekerasan terhadap orang-orang non-Muslim, orang-orang Cina, atau terhadap orang Islam yang tidak begitu saleh. Sikap kekerasan biasanya ditujukan kepada orang-orang yang menentang SI, sedangkan boikot dilakukan dalam bentuk acara-acara yang dinilai tidak sesuai dengan ajaran agama (budaya abangan) seperti pertunjukan kesenian rongeng, jaipong, gamelan, wayang, dan bahkan boikot dilakukan dalam bentuk tidak mau memandikan jenazah. Di daerah Muara Tembesi Jambi para anggota SI tidak lagi menghadiri pemekaman orangorang yang bukan anggotanya. Sikap-sikap seperti di atas cenderung dianut oleh golongan pembaharu daripada kalangan Islam tradisional yang cenderung toleran terhadap budaya tradisi lama yang hidup di tengah masyarakat.

Beberapa contoh peristiwa lainnya, di kampung Jatirawamangun distrik Jatinegara, anggota-anggota SI mengganggu pegelaran wayang topeng yang diselenggarakan seorang penduduk di rumahnya. Demikian pula di sebuah desa di afdeling Indramayu dan Cirebon di kediaman penduduk yang mengadakan pesta, ronggengronggengnya diculik oleh pengikut-pengikut SI sehingga gamelan tidak mungkin dimainkan. Bentrokan yang melibatkan anggota SI dengan orang Cina sangat banyak terjadi. Penyebabnya bisa saja hanya karena peristiwa kecil seperti kecelakaan yang menyebebkan korban penduduk pribumi, pemerkosaan wanita pribumi oleh orang cina. Bahkan ledakan anti Cina yang terjadi di Tambakbaya Rembang hanya dipicu oleh penembakan seekor kucing milik pribumi oleh orang Cina karena kucing tersebut mencuri sepotong daging ( Korver, 1985 : 129-163).

\section{SIMPULAN}

SI adalah organisasi terbesar dan sekaligus salah satu yang terpenting dalam sejarah Indonesia khususnya pada masa pergerakan nasional 1900-1942. Namun beberapa aspek eksistensinya hingga saat ini masih banyak belum dipahami oleh masyarakat peminat sejarah, termasuk dari kalangan akademisi. Aspek eksistensi itu adalah tentang kedudukan SI sebagai organisasi Islam dalam konteks dua arus besar umat Islam Indonesia yaitu Islam Tradisional dan Islam Modernis.

Banyak uraian sejarah yang tidak secara tegas menunjukan di mana posisi SI dalam pusaran arus besar tersebut, sehingga melahirkan kesimpulan bahwa SI hanyalah semata organisasi pergerakan Islam, yang tak dapat dikatakan sebagai organisasi Islam tradisional ataupun modernis. Akan tetapi banyak data akurat sejarah yang menunjukan bahwa SI sejatinya adalah organisasi pergerakan Islam modernis. Namun karena bidang kegiatan SI lebih dominan dalam bidang politik maka program-program organisasi dalam bidang sosial keagamaan menjadi terabaikan. Sebagaimana dinyatakan oleh Deliar Noer ... walaupun Partai Sarekat Islam mempunyai pemikiran pembaharuan dalam agama partai itu kurang terlibat dalam masalah-masalah yang dipertikaikan antara pihak pembaharu ( Kaum Muda ) dan pihak tradisi ( Kaum Tua ) dibandingkan dengan orang-orang atau organisasi-organisasi yang membatasi diri mereka pada bidang pendidikan dan sosial ( Noer, $1985: 151$ ). 


\section{DAFTAR PUSTAKA}

Benda, Hari J. Bulan Sabit dan Matahari Terbit Islam Indonesia Pada Masa Pendudukan Jepang. Jakarta Pustaka Jaya. 1985.

Deliar Noer. Gerakan Moderen Islam di Indonesia 1900-1942. Jakarta. LP3ES.1985

Geertz, Clifford. Abangan, Santri, Priayi dalam Masyarakat Jawa. Jakarta Pustaka Jaya. 1989.

Jang Aisjah Muthalib. Jambi 1900-1916 From War to Rebellion. Columbia University.1995

Korver, A.P.E. Sarekat Islam Gerakan Ratu Adil. Jakarta. Grafity Pers.1985

Mestika Zed. Kepialangan Politik dan Revolusi. Palembang 1900-1950. Jakarta. LP3ES.2002

Syaifullah. Gerak Politik Muhammadiyah Dalam Masyumi. Jakarta. Grafiti. 1997.

Taufik Abdullah (Ed). Sejarah Umat Islam Indonesia. Jakarta. Majelis Ulama Indonesia. 1991. 